NBER WORKING PAPER SERIES

\title{
INSURING CONSUMPTION AND HAPPINESS THROUGH RELIGIOUS ORGANIZATIONS
}

\author{
Rajeev Dehejia \\ Thomas DeLeire \\ Erzo F.P. Luttmer \\ Working Paper 11576 \\ http://www.nber.org/papers/w11576
NATIONAL BUREAU OF ECONOMIC RESEARCH
1050 Massachusetts Avenue
Cambridge, MA 02138
August 2005

The authors thank Bill Evans, Roland Fryer, Jonathan Gruber, and seminar participants at Duke University, the PSE Conference on Economics of Religion, and the Upjohn Institute for helpful comments and suggestions. We especially thank Roberta Gatti for helping us conceive of and begin this project. All errors are our own. This paper was completed while DeLeire was on leave from the Department of Economics at Michigan State University. The views expressed in this paper are those of the authors and should not be interpreted as those of the Congressional Budget Office. The views expressed herein are those of the author(s) and do not necessarily reflect the views of the National Bureau of Economic Research.

(O2005 by Rajeev Dehejia, Thomas DeLeire and Erzo F.P. Luttmer. All rights reserved. Short sections of text, not to exceed two paragraphs, may be quoted without explicit permission provided that full credit, including $\odot$ notice, is given to the source. 
Insuring Consumption and Happiness Through Religious Organizations

Rajeev Dehejia, Thomas DeLeire and Erzo F.P. Luttmer

NBER Working Paper No. 11576

August 2005, Revised June 2006

JEL No. D12, H31, J60, Z12

\section{ABSTRACT}

This paper examines whether involvement with religious organizations insures an individual's stream of consumption and of happiness. Using data from the Consumer Expenditure Survey (CEX), we examine whether households who contribute to a religious organization are able to insure their consumption stream against income shocks and find strong insurance effects for whites. Using the National Survey of Families and Households (NSFH), we examine whether individuals who attend religious services are able to insure their stream of happiness against income shocks and find strong happiness insurance effects for blacks but smaller effects for whites. Overall, our results are consistent with the view that religion provides an alternative form of insurance for both whites and blacks though the mechanism by which religious organizations provide insurance to each of these groups appears to be different.

Rajeev H. Dehejia

Department of Economics

Columbia University

420 W. 118th St., Rm. 1022

New York, NY 10027

and NBER

rd247@columbia.edu

Thomas DeLeire

Congressional Budget Office

U.S. Congress

Ford House Office Building

Second and D Streets, S.W.

Washington, DC 20515

thomas.deleire@cbo.gov
Erzo Luttmer

Kennedy School of Government

Harvard University

79 John F. Kennedy Street

Cambridge, MA 02138

and NBER

erzo_luttmer@harvard.edu 


\section{Introduction}

In the standard life-cycle model of consumption with perfect capital markets, the optimal consumption path is insensitive to transitory income shocks (Friedman 1957). In practice, however, individuals have only limited opportunities in the formal capital market to borrow against expected future income and, as a result, a range of alternative mechanisms has arisen to insure consumption against income shocks. Individuals may “self-insure" by holding extra savings (Leland 1968) or by having other household members increase their labor supply after a negative shock (Cullen and Gruber 2000).

Similarly, if markets are complete, consumption should not vary across individuals in response to idiosyncratic income shocks (Cochrane 1991, Mace 1991, Deaton 1992a). In practice, however, private insurance companies do not offer insurance against income risk, likely because private information about income prospects would lead to severe adverse selection. Given the trade-off between moral hazard and the value of insurance, the government only provides partial insurance against income risk, mainly through the tax and transfer system and programs like unemployment insurance.

Informal insurance provided by families, the local community, or social networks may overcome some of the adverse selection and moral hazard issues plaguing formal insurance, because these groups may be better able to monitor the behavior of those with income shocks and because selection into or out of such groups is costly. For example, Putnam (2000) argues that community (and hence also religious) organizations play an important role in providing social capital and in fostering norms of mutual aid and reciprocity among individuals. Iannaccone (1992) and Berman (2000) show that many of the costs of religious participation, such as adherence to religious strictures, can be 
rationalized as mechanisms to prevent free-riding on benefits provided by the religious group; in other words, religious organizations have mechanisms to limit adverse selection. Moreover, the monitoring of fellow members of the organization is likely to reduce moral hazard. One would therefore expect religious organizations to be well positioned to provide consumption insurance against income shocks, which is one of the hypotheses we investigate in this paper. ${ }^{1}$

Religious organizations also may influence their members in non-material ways, in particular by influencing beliefs, attitudes, and values. For example, Guiso, Sapienza, and Zingales (2003) suggest that religious belief is positively associated with attitudes conducive to economic growth. Similarly, religious beliefs can dampen or exacerbate the impact of stressful shocks on well-being by altering the value that the individual attaches to such a shock. For example, Clark and Lelkes (2005) show that, in cross-sectional European data, marital dissolution has a greater negative impact on the happiness of Catholics than the non-religious, but that members of all religious organizations experience a smaller impact of unemployment on happiness compared to non-members. In this paper, we use longitudinal U.S. data to examine whether members of religious organizations experience a smaller impact of income shocks on their subjective selfreported happiness. Such "happiness insurance" could both be driven by consumption insurance provided by the religious organization and by the members of religious organizations attaching less value to changes in material circumstances.

We use two data sources to examine whether religion provides insurance in response to income shocks: the Consumer Expenditure Survey (CEX) to examine

\footnotetext{
${ }^{1}$ This adds to the possible benefits of religious participation suggested by the literature, which include increased utility in the afterlife and the consumption of religious goods in the present (see, inter alia, Azzi and Ehrenberg 1975, Iannaccone 1990, and Biddle 1992).
} 
consumption insurance and the National Survey of Families and Households (NSFH) to examine happiness insurance. In our baseline specification, we find that religious participation (measured in the CEX as making any contribution to a religious organization) reduces the impact of income changes on consumption by roughly 40 percent. This estimate is mainly driven by white households, which constitute the majority of the sample. The consumption insurance effect is imprecisely estimated for blacks, and, as a result, we can neither reject that it is zero nor reject that it is as large for blacks as for the rest of the sample. We find marginally significant evidence of happiness insurance in the full sample, but this estimate is mainly driven by the black subsample. Blacks experience significant happiness insurance by regularly attending religious services; attending weekly rather than once a year approximately fully offsets the effect of income shocks on happiness. For whites, however, we find no statistically significant happiness insurance effect of religious attendance in the baseline specification, though the point estimate indicates that attending weekly rather than once a year offsets about one third of the effect of income shocks on happiness.

The finding that religious organizations serve an insurance function has two implications for government-provided social insurance. First, there will be less demand for social insurance in more religious areas and by more religious individuals, which is indeed what Stasavage and Scheve $(2005,2006)$ find using both individual-level data on preferences for social spending and country-level social insurance expenditure. Second, it implies that social insurance may crowd out insurance provided by religious organizations. Hungerman (2005) and Gruber and Hungerman (2005) show that government social insurance spending in fact crowds out religious charitable spending. 
The paper is organized as follows. In Section 2, we present a brief review of the literature. In Section 3, we discuss our two data sets. In Section 4, we outline our specifications and discuss identification issues. In Section 5, we present our results. Section 6 concludes.

\section{Previous Literature}

The first major study to examine the economics of religious participation is Azzi and Ehrenberg (1975). They model participation in church activities based on the idea that the stream of benefits from participation extends to the afterlife ("the salvation motive"), while they also allow that people derive enjoyment from church activities ("the consumption motive") and that religious membership can increase the probability of succeeding in business ("the social-pressure motive"). Their model implies that participation in church activities will increase with age because individuals are investing in the afterlife.

In an excellent overview of the growing literature on the economics of religion, Iannaccone (1998) discusses a range of studies of the economic consequences or correlates of religious participation, for example Freeman's (1986) finding that blacks that attend church are less likely to smoke, drink, or engage in drug use. Iannaccone also reviews models of religious participation, including those of "religious capital", which can help to explain why religious participation increases later in life and why as wages increase religious participation will be reflected to a greater extent through contributions rather than though attendance. Using the CEX and the General Social Survey, Gruber 
(2004) provides evidence for this hypothesis, finding an implied elasticity of attendance with respect to religious giving of -0.9 .

More recent studies have focused on the consequences of religious participation. Gruber (2005) finds that increased religious participation leads to higher educational attainment and income, less dependence on social insurance programs and higher rates of marriage. To establish causality, he instruments an individual's own religious attendance by the local density of other ethnic groups sharing the same denomination. Using micro data, MacCulloch and Pezzini (2004) find that religious participation reduces the taste for revolution, while based on macro data, Barro and McCleary (2003) argue that there is a causal link between religiosity and economic growth.

There is also a large literature examining the correlation between religious participation and subjective measures of wellbeing and distress (Diener et al. 1999, Parmagent 2002, and Smith et al. 2003). ${ }^{2}$ While we know of no other study looking at the ability of religious participation to buffer against income shocks, a number of studies find that it can attenuate the effect of traumatic events on subjective wellbeing or depression (Ellison 1991 and Strawbridge et al. 1998). Based on European data, Clark and Lelkes (2005) find that religiosity may dampen or exacerbate the happiness effect of a traumatic event depending on the denomination and the type of the event.

Religious organizations may be one of many institutions that provide informal insurance. Families can help insure their members against shocks, though evidence suggests that in the U.S. insurance provided by families is far from perfect (Cox 1987 and Altonji et al. 1997). In developing countries, there is considerable evidence of

\footnotetext{
${ }^{2}$ There is also a large literature on the correlation between religious belief and health outcomes. See, for example, McCullough et al. (2000).
} 
households partially sharing income risk (Deaton 1992b and Townsend 1994). This has spawned a large literature on self-enforcing risk-sharing agreements and other informal insurance schemes such as group lending or mutual credit (for example, Foster and Rosenzweig 2001, Gertler and Gruber 2002, and Genicot and Ray 2003). Religion has received relatively little attention in this context with the notable exception of Chen (2004), who shows that individuals particularly affected by the Asian financial crisis were more likely to increase their religious participation and interprets this as religious organizations providing "ex-post" insurance for individuals hit by negative shocks.

\section{Data}

The data for our empirical analysis come from two sources. First, we use the CEX to examine whether participation in religious organizations (measured by financial contributions to these organizations) provides consumption insurance against changes in income. Second, we use the NSFH to examine whether participation (measured by attendance at religious services) provides happiness insurance against changes in income.

\subsection{The Consumer Expenditure Survey}

We use data from the 1986 through 2000 panels of the Consumer Expenditure Survey (CEX). ${ }^{3}$ The CEX is a nationally representative survey of roughly 5,000 households per year, is the basic source of data for the construction of the items and weights in the market basket of consumer purchases to be priced for the Consumer Price Index, and is widely regarded as the best source of U.S. consumption expenditure data. It

\footnotetext{
${ }^{3}$ Beginning in 2001, the CEX changed the way in which it collected information on contributions. We only use data up to 2000 to help ensure that the data is comparable across years.
} 
contains information on the characteristics of each household member including their relationships, income and demographics, as well as detailed household-level information on expenditures. Each household is interviewed up to four times at three-month intervals. Three months of expenditure data are collected retrospectively at each quarterly interview. Income over the past 12 months is asked only in the first and fourth interviews. In the fourth interview, data on five types of contributions - contributions to religious organizations, charitable organizations, political organizations, educational organizations, and miscellaneous contributions — over the past year are collected.

We consider two measures of consumption based on the expenditure data reported in the CEX, non-durable consumption and total consumption. Non-durable consumption consists of expenditure on food to be consumed in the home, food consumed outside of the home, alcohol, tobacco, clothing, personal care, and transportation. Total consumption includes non-durables plus durables (furniture, appliances, and consumer goods), housing, and housing related expenses (home mortgage interest and home maintenance). We prefer using expenditures on non-durables as our measure of consumption because expenditures on durables do not measure the consumption flow from them and, therefore, provide a rather noisy measure of true consumption. Consumption of goods provided in-kind is not measured in the Consumer Expenditure Survey. We measure the change in consumption as the difference in log quarterly expenditure between the first and last interviews. Our measure of income is log real household income (in 1998 dollars) and the change in household income is the difference in log income between the first and fourth interviews. 
We use contributions to religious organizations as our measure of religious participation. About 40 percent of households make a contribution to a religious organization and these contributions represent about 1.2 percent of household income in the CEX. These findings are consistent with other sources; according to Iannaccone (1998), total religious contributions represent roughly 1 percent of GNP.

\subsection{National Survey of Families and Households}

We use the first two waves of the NSFH, a nationally representative sample of individuals, age 19 or older, living in households, and able to speak English or Spanish (Sweet, Bumpass, and Call 1988 and Sweet and Bumpass 1996). The first wave of interviews took place in 1987-88, and a second wave of interviews took place in 1992-94. Though the questionnaires are not identical in both waves, many questions were asked twice making it possible to treat the data as a panel of about 10,000 individuals.

The main outcome variable we use is self-reported happiness, which is the answer to the question: "Next are some questions about how you see yourself and your life. First taking things all together, how would you say things are these days?" Respondents answered on a seven-point scale where 1 is defined as "very unhappy" and 7 is defined as "very happy" but intermediate values are not explicitly defined. Because this question is asked in both surveys, we are able to measure the change in individual-level happiness between 1987/88 and 1992/94. The use of self-reported happiness measures has become increasingly popular in economics; see, for example, Frey and Stutzer 2002, Blanchflower and Oswald 2004, and Gruber and Mullainathan 2005. One of the 
conclusions of this literature is that self-reported happiness is a useful proxy for wellbeing, and responds to economic variables as expected.

We use attendance of religious services as a measure of participation in religious organizations. In our baseline specification we use the percentile location of an individual in the distribution of attendance, but we also use a dummy for attending more than the median as a robustness check. The distribution of religious service attendance is reported in Table 1.

\subsection{Baseline Sample}

Of the 100,549 households interviewed in the 1986 through 2000 panels of the CEX, 44,270 households are present in both the first and fourth interviews and were not coded by the BLS as an incomplete income respondent. In the NSFH 7,486 main respondents have non-missing happiness in both waves, out of a total of 10,005 observations in the NSFH panel. In both the CEX and the NSFH, we restrict the baseline sample to those where the head and spouse are under the age of 60 at the last interview in order to minimize the relatively predictable income shock from retirement. This restriction yields a final CEX sample of 31,787 households of which 27,190 are white, 3,322 are black, and 1,275 are of other races, while the final NSFH sample consists of 5,716 respondents of which 4,697 are white or Hispanic, 924 are black, and 95 are from other race/ethnic groups. 


\section{Empirical Strategy}

\subsection{Specifications}

Our empirical test of whether religious organizations help insure their members against income shocks consists of two parts. First, using the CEX, we examine whether religious contributions insure a household's consumption against changes in income, and second, using the NSFH, we examine whether religious attendance buffers an individual's happiness against income shocks.

To examine whether religious affiliation insures a household's consumption or an individual's happiness, we run regressions of the form:

$$
\Delta \text { Outcome }_{i}=\Delta \text { Income }_{i} \beta_{1}+\text { Relig }_{i} \beta_{2}+\Delta \text { Income }_{i} \times \operatorname{Relig}_{i} \beta_{3}+\boldsymbol{X}_{i} \beta_{4}+\delta_{t}+\varepsilon_{i},
$$

where $\Delta$ Outcome $_{i}$, is either the change in log consumption or the change in happiness, $\Delta$ Income $_{i}$ is the change in log income, Relig $i$ the measure of religiosity (contributions in the CEX, attendance in the NSFH) and $\boldsymbol{X}_{i}$ an extensive set of demographic controls in levels and first differences. Finally, $\delta_{t}$ is a set of month $\times$ year-of-interview dummies and $\varepsilon_{i}$ is an error term. ${ }^{4}$

Unless indicated otherwise, all variables in levels are the average of the responses in both interviews and all variables in first difference are the response in the last interview minus the response in the first interview. ${ }^{5}$ In our baseline specification, we use

\footnotetext{
${ }^{4}$ Because in the NSFH the time period between the first and second interview is not always the same, we include both a full set of month $\times$ year dummies for the first interview and a full set of month $\times$ year dummies for the second interview. In the CEX, the time period between interviews is constant, so a single set of month $\times$ year dummies suffices.

${ }^{5}$ This specification ensures that the variables in levels and first differences are orthogonal by construction. We therefore do not have to worry that the estimate on the level variable is affected by noise in the first difference variable.
} 
$\log$ household income rather than log per capita household income as our measure of income. While changes in per capita income may be a more accurate measure of the severity of an income shock, per capita income can also change because of other life events such as marriage, childbirth or death. The direct impact of these life events on happiness may depend on religious attendance, thus possibly contaminating our estimates of insurance. We also top and bottom code the change in log income at $+/-100 \log$ points around the race-specific mean income change in order to rule out that a few observations with exceptional income shocks drive our estimates.

Under complete consumption insurance, changes in own income should not affect changes in own consumption or own happiness once changes in economy-wide consumption (in this case, captured by $\delta_{t}$ ) have been controlled for. That is, a finding that $\beta_{l}$ is zero can be interpreted as evidence in favor of complete insurance. Generally, most studies in the consumption literature reject complete consumption insurance (see, for example, Cochrane 1991, Nelson 1994, and Attanasio and Davis 1996), though some do not (see, for example, Mace 1991). In the happiness literature, most studies with large enough sample sizes find a significant positive effect of changes in own income on changes in happiness, though a substantial part of this effect appears to be only temporary (Diener and Biswas-Diener 2002, Di Tella et al. 2005, and Gardner and Oswald, 2005).

If religious organizations provide insurance for their members, changes in income should have a smaller effect on the outcome variable for their members, yielding a negative coefficient on the interaction term. Thus, an estimate of $\beta_{3}<0$ is consistent with religious organizations providing insurance. 


\subsection{Econometric Issues}

A. Measurement error in income

A major concern is that income is measured with error. Thus, changes in income will be noisy and will lead to potentially severe downward bias in $\beta_{1}$, the effect of income on consumption or happiness. Fortunately for our objective, to assess whether religious membership provides insurance, we do not need to assess the effect of income on expenditure. Rather, we need to compare the effect of income on consumption or happiness for participants compared to non-participants. Unless measurement error in income varies with religious participation, the measurement error should lead to the same bias in $\beta_{1}$ and $\beta_{3}$, and the ratio of $\beta_{1}$ to $\beta_{3}$ should be unaffected by measurement error. ${ }^{6}$

\section{B. Measurement error in religious participation}

The CEX does not measure religious participation by attendance but rather by contributions to religious organizations. By contrast, the NSFH measures attendance. An important issue is whether contributions effectively measure participation. Unfortunately, we are unable to assess this directly because the CEX reports contributions but not attendance while the NSFH reports attendance but not contributions. Iannaconne (1998), however, reports that the determinants of religious participation are similar regardless of whether one measures participation by attendance or by contributions. The contribution to religious organizations is only measured in the last interview in the CEX. We discuss whether the timing of the measurement of religious

\footnotetext{
${ }^{6}$ In Dehejia, DeLeire, and Luttmer (2005) we examine whether income volatility varies by religious participation as a rough indicator of differential measurement error by religious participation. We find no large differences in income volatility by religious participation.
} 
contributions could mechanically explain our findings in Section 5.1, but we conclude that this is unlikely.

C. Endogeneity of religious participation with respect to income shocks

A concern with using religious participation as an independent variable in our specifications is that it could be endogenous with respect to income shocks that have a smaller impact on consumption or happiness (e.g., if those with temporary negative shocks would be more likely to increase attendance than those with permanent negative shocks). This has been suggested by the recent work of Chen (2004) in Indonesia. While we cannot test for such a differential effect directly (because we cannot distinguish permanent from temporary shocks), we examine whether income shocks in general affect attendance using data from the NSFH and find only a very small and statistically insignificant effect of income shocks on attendance; a negative income shock of $100 \log$ points would increase attendance by 0.6 percentiles (results not presented; see Dehejia, DeLeire, and Luttmer 2005). Thus, while our effect goes in the same direction as Chen's (2004) finding for Indonesia, the magnitude of the effect is not economically meaningful in the U.S. Given the small magnitude of this effect, we will use average attendance over the two waves in our subsequent specifications, because this reduces measurement error in the attendance variable. ${ }^{7}$

In the CEX, contributions are measured in the final period, and thus it is a concern if changes in income affect religious contributions. It is unclear in which direction the bias will go. On the one hand, if positive income shocks are more likely to be permanent income shocks than negative ones and if people are more likely to contribute after a

\footnotetext{
${ }^{7}$ We use average attendance in both periods, but find similar results if we use first period attendance.
} 
positive shock, then those who contribute disproportionately experienced permanent income shocks and therefore have a greater consumption response to the income shock. This would bias us away from finding consumption insurance effects. On the other hand, if negative shocks were disproportionally permanent shocks and if those experiencing a loss are less likely to contribute, then the bias would go the other way.

D. Does religious involvement proxy for other characteristics that provide insurance?

While all our regressions include an extensive list of household and individual control variables, one may be concerned that religious participants have different observable characteristics and that these characteristics explain their lower sensitivity to income shocks. We deal with this concern in three ways. First, we create a matched sample in which each religious participant is matched to a non-participant using the nearest-neighbor method such that the predicted probability of being a participant is roughly equal for the participant and non-participant. ${ }^{8}$ Thus, the matching procedure creates a sample in which the distribution of observable characteristics, to the extent they correlate with religious participation, is similar for participants and non-participants. When we run our regression on this matched sample, we are less concerned about the insurance effect of religious participation being driven by differences in observable characteristics.

\footnotetext{
${ }^{8}$ For purposes of the matching routine a religious participant is defined as a religious contributor in the $\mathrm{CEX}$ and as someone with religious attendance above the own-race median in the NSFH. A nonparticipant matched to multiple participants is only entered once in the regression but with a weight that is equal to the number of participants to which it was matched. While the matched sample contains all participants, some non-participants may not be matched. Thus, the matched sample contains fewer observations than the original sample.
} 
Second, we not only interact the income shock with actual religious participation, but we also include an interaction with predicted religious participation, where the predicted value is based on the observable characteristics included as controls in our regression. A finding that the insurance effect is driven by actual religious participation rather than predicted religious participation is suggestive evidence that the insurance effect comes from religious participation rather then observable characteristics correlated with religious participation.

Third, we control for as many of the omitted variables for which religion could be a proxy as possible. In particular, the concern is that religious attachment could pick up individuals who are more risk averse (hence likely to have other forms of insurance) or more patient (hence likely to have greater savings and the ability to self-insure). Thus, we control for whether or not individuals buy other forms of insurance and, in some specifications, for homeownership and their level of wealth and financial assets.

We also conduct a number of additional checks that help alleviate our concern that potentially unobservable differences between participants and non-participants may be driving our results. ${ }^{9}$ First, we determine whether our estimates of the insurance effect change as we add blocks of control variables to our models. Second, we determine how sensitive our estimates are to the addition of controls for wealth, homeownership and insurance interacted with changes in income. These simple tests help to determine whether religious participation is merely a proxy for unobservable individual characteristics that drive the insurance effect.

\footnotetext{
${ }^{9}$ These additional checks are simple versions of the procedures formalized in Altonji, Elder, and Taber (2005) that use the amount of selection on observable variables as an estimate of the amount of potential selection on unobservable variables.
} 


\section{Results}

\subsection{Does Religious Participation Provide Consumption Insurance?}

In this section, we report results from our analyses using the CEX to examine whether religious participation, as measured by making a contribution to a religious organization, insures consumption against changes in income. Table 2, panel A, reports our baseline specification. ${ }^{10}$ In the first column, we see that changes in log household income are positively associated with changes in log non-durable consumption: for a noncontributor, a one-percent increase in income leads to a 0.115 percent increase in consumption, which implies incomplete consumption insurance. Households who are religious contributors do not have consumption growth that is different than noncontributors. Does religious membership offset the association between changes in income and changes in non-durable consumption? The coefficient on the interaction term between changes in log household income and membership in a religious organization is -0.046 and is significant at the ten percent level. We calculate the "implied degree of insurance" as the fraction by which religious membership reduces the consumption response to income shocks: $0.046 / 0.115=39.7$ percent, which is significant at the one percent level. $^{11}$

\footnotetext{
${ }^{10}$ The regression also includes the following controls: log real household income, a dummy for income being zero or missing, average age of head and spouse, age squared/100, household size, the change in household size between interviews, the presence of children in the household, the change in the presence of children between interviews, education (dummy variables for high school graduate, some college, college graduate, professional degree), marital status (dummy variables for widowed, divorced, separated, and never married), change in marital status, a dummy for owning a life insurance policy, and year by month dummies. In results, not shown, in which we only include control variables measured in changes, our results change little: the implied insurance effect for whites becomes $0.401(0.096)$.

${ }^{11}$ It may seem surprising at first that the interaction term $(-0.046)$ only has a p-value of 0.08 but that the implied degree of insurance is statistically significant at the 1 percent level. The reason for this is that the coefficient on income changes and the coefficient on the interaction are positively correlated due to sampling variation and that, as a result, their ratio is more precisely estimated.
} 
In the second column, for white households, we find a similar implied degree of insurance of 40 percent. For black households, reported in the third column, we see an even larger implied degree of insurance, but one that is not statistically significant. However, given the relatively large standard error, we cannot reject a hypothesis that the insurance effect for black households is equal to that of white households.

In panels B through $\mathrm{G}$ of Table 2, we report a number of specification checks and sensitivity analyses. ${ }^{12}$ In panel B of Table 2 , we present results in which we also add predicted religious participation (from a probit of religious participation on log household income, the full set of demographic controls described above, and a full set of year by month dummy variables) and the interaction of predicted religious participation with the change in log household income. The results show that the insurance effect does not appear to be driven solely by observable differences in demographics between contributors and non-contributors. ${ }^{13}$

In panel $\mathrm{C}$ of Table 2, we report results using the matched sample. The estimated degree of insurance of religious participation in the matched sample is very similar to our estimate using the original sample. This confirms the conclusion from panel B that the

\footnotetext{
${ }^{12}$ Further robustness checks are presented in Dehejia, DeLeire, and Luttmer (2005): we measure income and consumption in per capita terms; we remove the top and bottom coding of income changes; and we define religious membership as a dummy variable equal to 1 if a household contributes more than the racespecific median contribution, conditional on the contribution being positive to religious organizations in a year. The results of these robustness checks are very similar to our baseline results. In other robustness checks, which are not shown, we allow for separate insurance effects for increases and decreases in income; we find that our insurance effects are driven by smaller consumption responses to declines in income: for whites, the implied degree of insurance for downward shocks is $1.179(0.354)$ but for upward shocks it is 0.185 (0.341), a statistically significant difference at the five percent level.

${ }^{13}$ In an additional specification check, we fully interact the indicator for religious participation with all control variables. The results change little when we do this: e.g. the implied degree of insurance for whites becomes 0.411 (0.098).
} 
results are not driven by observable characteristics that are correlated with religious participation. $^{14}$

In panel $\mathrm{D}$, we examine whether charitable contributions also have an insurance effect on households. While it is conceivable that some types of charitable contributions could also provide households with the kind of social capital that could provide insurance in times of need, this does not seem plausible for most charitable contributions. Thus, if we were to observe charitable contributions also yielding an insurance effect, we would be concerned that the estimated insurance effect is an artifact of contributions (religious or charitable) being measured only in the last interview or that making contributions is a proxy for an omitted variable that provides the insurance effect. In panel $\mathrm{D}$, however, when we add an indicator for the household having made a charitable contribution and an interaction between having made a charitable contribution and the change in log household income, we see that charitable contributions do not have a significant insurance effect on consumption, reducing concerns about the causal interpretation of the insurance effect of religious contributions.

In panel $\mathrm{E}$, we use the change in log total consumption expenditure as our dependent variable instead of using just the non-durable component. The results show that we continue to find substantial insurance effects for the total sample and for white

\footnotetext{
${ }^{14}$ In additional analyses (not reported), conducted to help alleviate the concern that unobservable differences might be responsible for our results we, first, determine whether our estimates of the insurance effect change as we add blocks of control variables to our models and second, we determine how sensitive our estimates are to the addition of controls for wealth, homeownership and insurance interacted with changes in income. When adding blocks of controls, we start with only demographic controls, add controls for education, add the level of income as control, and finally add all remaining controls. We find that the implied degree of insurance changes very little: e.g. for whites it is $0.394(0.093), 0.396(0.092), 0.395$ (0.093), and $0.386(0.097)$ respectively. Also when we add additional interactions with income changes, the implied degree of insurance changes little: e.g. for whites it is $0.492(0.206), 0.336(0.106), 0.355$ $(0.156)$, and $0.398(0.233)$ respectively as we interact income changes with wealth, homeownership, insurance, and finally all three.
} 
households when using total consumption. In panel F, we drop the age restriction that we imposed on our sample in order to avoid retirement-related income shocks. The estimated insurance effects without the age restriction are similar to our baseline results for the significant effects.

In Table 3, we split the results by the education level of the household head (high school or less versus more than high school), by household wealth, and by income. ${ }^{15}$ There are two motivations for this. First, the willingness of religious organizations to insure their members may vary by education, wealth, or income (with organizations plausibly being more willing to insure low-skill, low-wealth, or low-income members). Second, access to alternative, formal sources of insurance could also vary by education, wealth, and income. We find a significant insurance effect for the low-education, lowwealth, and low-income white samples, generally somewhat larger in magnitude than the results for whites in our baseline specification. For the high-education and high-wealth white subsamples, we find no significant insurance effect of religious participation though we do find a significant insurance effect (at the 10 percent level) for the highincome white subsample. Thus, consistent with our priors, religious organizations mostly provide consumption insurance to more needy households. For black households, we find a marginally significant insurance effect for the low-education subsample.

\subsection{Does Religious Attendance Provide Happiness Insurance?}

In Table 4, we report the results of our analyses using the NSFH to examine whether religious participation can buffer the happiness consequences of income shocks.

\footnotetext{
${ }^{15}$ We report results only for white and black households. Results for the full sample are very similar to those for the white sample.
} 
The first column of panel A presents our baseline specification for the full sample. As before, a negative coefficient on the interaction term can be interpreted as religious participation providing an insurance effect. We estimate the implied degree of insurance as the degree to which going from the $25^{\text {th }}$ percentile of the attendance distribution (roughly attending once a year) to the $75^{\text {th }}$ percentile (attending weekly) reduces the impact of an income shock on happiness. ${ }^{16}$ The implied degree of insurance for the full sample is $65 \%$ and statistically significant at the $10 \%$ level. Thus, roughly speaking, active religious participation buffers about two thirds of the reduction in happiness from a negative income shock.

In columns (2) and (3), we restrict the samples to whites and to blacks and find that our results are driven primarily by blacks. For whites, the estimate of the implied degree of insurance is about a third, but it is not statistically significant. For blacks, however, the implied degree of insurance is significant at the 1 percent level and the point estimate suggests roughly full insurance. It is intriguing that our consumption insurance effects primarily show up for whites while the happiness insurance effects are strongest for blacks. We discuss and interpret this finding more extensively in Section 6.

Panels B and C of Table 4 explore whether the baseline results could be driven by differences in observable characteristics between active religious participants and less active ones. In panel B, we interact income shocks both with actual and with predicted religious attendance. We find that actual rather than predicted religious attendance drives

\footnotetext{
${ }^{16}$ We measure the implied degree of insurance as the effect of a 50 percentile point increase in attendance for comparability with Table 2 : if we had measured attendance as a dichotomous variable (like membership in Table 2), the average attendance among the high attendance group would by definition be 50 percentile points higher than the average attendance in the low attendance group. Formally, the implied degree of insurance is calculated as $-0.5 \beta_{3} /\left(\beta_{1}+0.25 \beta_{3}\right)$, where $\beta_{1}$ is the coefficient on the change in income, $\beta_{3}$ is the coefficient on the interaction term, and $\left(\beta_{1}+0.25 \beta_{3}\right)$ is the happiness sensitivity to income shocks of someone at the $25^{\text {th }}$ percentile of the attendance distribution. In specification $\mathrm{E}$, where attendance is measured by a dummy variable, the implied degree of insurance is given by $-\beta_{3} / \beta_{1}$.
} 
our baseline results. Thus actual religious attendance, rather than observable

characteristics correlated with attendance, provides the insurance effect. ${ }^{17}$ In panel C, we match each individual with above-median religious attendance to an individual with below-median attendance that has the same predicted probability of attending above the median, where the prediction is based on same set of control variables as in our baseline specification. We find that the insurance effects in our matched sample are very similar to those in our baseline sample, though the estimate is no longer marginally statistically significant for the full sample. ${ }^{18}$

Panels D to F provide robustness checks for the happiness insurance results that are analogous to those provided for the consumption insurance results in Table 2. In particular, we test the sensitivity of our baseline results to: in panel $\mathrm{D}$, running the regressions as an ordered probit rather than OLS; in panel E, measuring religious attendance with an indicator for attending more than the race-specific mean; and, in panel F, eliminating the age restriction. ${ }^{19}$ In all cases, the insurance effect of religious participation is statistically significant for blacks, with point estimates generally indicating close to full insurance. For whites, the insurance effect is never statistically

\footnotetext{
${ }^{17}$ In two additional specification checks, in which we fully interact the indicator for religious participation with all control variables and we only include control variables measured in changes. Our results change little: the implied insurance effects for blacks become $1.18(0.29)$ and $1.15(0.30)$, respectively.

${ }^{18}$ In additional analyses (not reported), conducted to help alleviate the concern that unobservable differences might be responsible for our results, we first determine whether our estimates of the insurance effect change as we add blocks of controls variables to our models and, second, we determine how sensitive our estimates are to the addition of controls for wealth, homeownership and insurance interacted with changes in income. When adding blocks of controls, we starting with only demographic controls, add controls for education, third add the level of income as control, and finally add all remaining controls, and find that the implied degree of insurance changes very little: e.g. for blacks it is $1.16(0.31), 1.17(0.31)$, $1.16(0.32)$, and $1.25(0.38)$ respectively. Also when we add additional interactions with income changes, the implied degree of insurance changes little: e.g. for blacks it is $1.25(0.40), 1.22(0.35), 1.13(0.36)$, and $1.20(0.44)$ respectively as we interact income changes with wealth, homeownership, insurance and all three.

${ }^{19} \mathrm{We}$ also test the sensitivity of our baseline results to measuring income in per capita terms, eliminating the top and bottom coding of income shocks, and measuring religious attendance as times per month rather than as percentiles. The results, reported in Dehejia, DeLeire, and Luttmer (2005), are very similar.
} 
significant, though the point estimates generally indicate a degree of insurance that is economically meaningful. ${ }^{20}$

In Table 5, we examine the insurance effect of religious attendance for subsamples of the data. We split the sample by education, liquid financial assets, per capita income, and the intensity of religious belief. In panel A among black individuals, we find a significant insurance effect for less educated individuals. For more educated individuals, we find an insurance effect, but one that is not statistically significant. Among whites, the implied degree of insurance for the less educated is large but not statistically significant, whereas for the more educated there is an insignificant effect in the opposite direction. In panels B and C, when we split the data by financial assets and by per capita income, which are presumably closely correlated with education and each other, we get very similar results. Thus, these findings echo the earlier consumption insurance results: the insurance effects are strongest for less educated, lower wealth and lower income individuals, whether it concerns consumption insurance (Table 3) or happiness insurance (Table 5).

Finally, in panel D, we split our results by intensity of religious beliefs as measured by the average response to two statements about the Bible. ${ }^{21}$ We find that those with the greatest intensity of beliefs experience the largest insurance effect; among blacks this effect is significant and large in magnitude, and among whites this effect

\footnotetext{
${ }^{20}$ In other robustness checks, which are not shown, we allow for separate insurance effects for increases and decreases in income; we find that our insurance effect is somewhat stronger for negative income shocks, but the insurance effect is no longer statistically significant when we restrict shocks to only positive or only negative shocks. Hence, we lack power to distinguish whether the insurance effect is driven by positive or negative shocks.

${ }^{21}$ Because this question is only relevant for Christians, we drop those reporting a non-Christian religious affiliation from the sample in panel D. The statements are "The Bible is God's word and everything happened or will happen exactly as it says" and "The Bible is the answer to all important human problems" and the response to each statement was recorded on a 5-point scale from "strongly agree" to "strongly disagree."
} 
points in the direction of insurance though it is not significant. Various mechanisms could give rise to this finding. Religious organizations could treat all participants equally but those with more intense beliefs might receive more doctrinal solace from attending after experiencing a negative income shock. Alternatively, those with more intense beliefs may be more attached to their religious organization (in ways not captured by frequency of attending religious service) and the religious organization may channel assistance to more attached members. However, in unreported regressions, we found that the intensity of beliefs by itself does not provide happiness insurance against income shocks. Thus, just believing is not sufficient; one needs to participate in a religious organization to receive happiness insurance. ${ }^{22}$

It will not be possible for our results to distinguish between the spiritual, social and material channels though which religious participation may provide happiness insurance. However, by examining the insurance effect of other social activities, we can at least determine whether religious organizations play a special role in this regard. These results are presented in Table 6. In panel A, we interact a range of social activities with income shocks. For blacks, we find that all social activities go in the direction of providing insurance for happiness against income shocks, but that only getting together socially and going to social events at a church, synagogue or mosque are marginally statistically significant. For whites, all activities (other than going to a bar) go in the direction of insurance, but none are even close to statistical significance. In panel B, we examine the effect of participating in organizations such as political and service groups, leisure groups, work-related activities, and religious organizations. These activities

\footnotetext{
${ }^{22}$ Another split we consider is by religious denomination (available for the NSFH but not the CEX) and examine whether religious participation insures against shocks other than income. We do not find any significant results; see Dehejia, DeLeire, and Luttmer (2005).
} 
generally do not provide a statistically significant degree of insurance, except for whites active in service or political organizations and blacks participating in church-related events (other than religious service). We conclude that participation in religious organizations stands out from other measures of social capital in its ability to provide happiness insurance against income shocks.

\subsection{Discussion}

We find it interesting that the mechanism behind the insurance effects of participation in religious organizations appears to differ by race. However, given that our results are based on two different outcomes and two different measures of religious participation and because there are no statistically significant differences in the insurance effects between blacks and whites, our results are merely suggestive that the form of insurance provided by religious organizations differs by race.

Of course, because we use the same measure of participation for blacks and whites within each data set, the difference in measures alone is unlikely to explain the differences in insurance effects by race. By contrast, if either attendance or contributions differentially measures participation for blacks and whites, then this difference could explain the differences in insurance effects by race. For example, this could arise if all white participants, but not all black participants, of religious organizations make contributions or if all black participants, but not all white participants of religious organizations attend religious services. For this reason, our statistical confidence that the form of insurance provided by religious organizations differs by race is limited. 
Nonetheless, this finding is consistent with evidence from the sociological literature. Cnaan (2002) finds that percent white membership of a congregation is a significant and positive predictor of a congregation's financial commitment to giving, even after controlling for the income and total budget of the congregation. Chaves and Higgins (1992) find that the form in which members of religious organizations help each other differs by race. Mutual help in black churches is more likely to be in-kind (and thus less likely to be measured by the CEX) while mutual help in white religious organizations is more likely to be in cash or as a loan (thus showing up in expenditures in the CEX). Nelson (1997) notes that the level of trust between different families belonging to the same church is often remarkably low in poor black communities, and that this lack of trust may also inhibit short-term loans between members of the church community.

The relatively small and insignificant happiness insurance effect for whites suggests a stigma attached to receiving assistance, though we do not have direct evidence for this. Furthermore, moral or doctrinal support for those experiencing difficulties tends to be greater in black churches than in white churches, leading to substantial happiness insurance. Nelson (2004), for example, notes that many poor black church members place less emphasis on material sources of happiness; instead, they view those in the middle class as people "who had lost their religious fervor by becoming too concerned with material goods." For many African Americans, the church is the community (Carson 1990). Church services tend to be community-oriented and relatively long (often over 2 hours), and there are many well-attended social and community related church events. Thus, relative to whites, African Americans who do not belong to a church may have fewer alternative sources of (emotional) support when they fall on hard times. 
While these explanations seem plausible, further research on the exact mechanisms by which religious organizations provide insurance remains desirable.

One drawback of the data we use to identify the insurance effects of participation in religious organizations is that we cannot identify the mechanism by which this participation buffers against changes in income. The amount of cash assistance provided by religious organizations would have to be large to explain these insurance effects. Alternatively, participating in religious organizations may provide individuals with sufficient contacts within their community to enable them to receive aid directly from other individuals when required.

One likely mechanism by which religious organizations may provide consumption insurance is by allowing their members to reduce the amount of their contributions in years following a reduction in their income. By doing so, members would be able to reduce other forms of consumption by less. From our analysis using the $\mathrm{NSFH}$, we observe no decline in attendance in response to a change in income. ${ }^{23} \mathrm{~A}$ decline in contributions in response to a change in income, therefore, would be a form of insurance since the religious organizations would be continuing to provide services while allowing the member to make fewer (or no) contributions.

Unfortunately, we are unable to identify the extent of this possible insurance mechanism since we only observe annual religious contributions in the fourth interview in the CEX data.

${ }^{23}$ These results are reported in Dehejia, DeLeire, and Luttmer (2005). 


\section{Conclusion}

We find that religious participation partially insures consumption and happiness against income shocks. This finding has important implications for the public provision of social insurance. Social insurance is less valuable for those who are already partly insured through their religious organization, implying that the optimal level of social insurance is inversely related to the religious participation of the population. ${ }^{24}$ Conversely, social insurance can crowd out insurance provided by religious organizations. Thus, even where church and state are officially separated, governments providing less social insurance will indirectly stimulate the demand for insurance from religious organizations and thus mostly likely strengthen the influence of religious organizations.

\footnotetext{
${ }^{24}$ Of course, insurance provided by religious organizations may crowd out other forms of private insurance, such as that provided by extended families.
} 


\section{References}

Altonji, Joseph G., Todd E. Elder, and Christopher Taber (2005). "Selection on Observable and Unobservable Variables: Assessing the Effectiveness of Catholic Schools." Journal of Political Economy, 113(1):151-184.

Altonji, Joseph G, Fumio Hayashi, and Laurence J. Kotlikoff (1997). "Parental Altruism and Inter Vivos Transfers: Theory and Evidence." Journal of Political Economy, 105(6): 1121-1166.

Attanasio, Orazio and Steven J. Davis (1996). "Relative Wage Movements and the Distribution of Consumption." Journal of Political Economy, 104(6): 1227-1262.

Azzi, Corry and Ronald G. Ehrenberg (1975). "Household Allocation of Time and Church Attendance.” Journal of Political Economy, 83(1): 27-56.

Barro, Robert J., and Rachel McCleary (2003). "Religion and Economic Growth." National Bureau of Economic Research Working Paper No. 9682.

Berman, Eli (2000). "Sect, Subsidy, and Sacrifice: An Economist's View of Ultraorthodox Jews." Quarterly Journal of Economics, 115(3): 905-953.

Biddle, Jeff E. (1992). “Religious Organizations.” In Charles T. Clotfelter (ed.), Who Benefits From the Non-Profit Sector? Chicago: University of Chicago.

Blanchflower, David G. and Andrew J. Oswald (2004). "Well-Being over Time in Britain and the USA," Journal of Public Economics, 88(7-8): 1359-1386.

Carson, Emmett (1990), "Patterns of Giving in Black Churches." In Robert Wuthnow and Virginia Hodgkinson (eds.), Faith and Philanthropy in America: Exploring the Role of Religion in America's Voluntary Sector. San Francisco: Jossey-Bass Publishers: 232-252.

Chaves, Mark, and Lynn Higgins (1992), "Comparing the Community Involvement of Black and White Congregations," Journal for the Scientific Study of Religion, 31(4): 425-440.

Chen, Daniel (2004). "Club Goods and Group Identity: Evidence from the Islamic Resurgence During the Indonesian Financial Crisis." manuscript, University of Chicago.

Clark, Andrew and Orsolya Lelkes (2005) "Deliver us from Evil: Religion as Insurance." manuscript, PSE, Paris.

Cnaan, Ram (2002). The Invisible Caring Hand: American Congregations and the Provision of Welfare. New York: New York University Press. 
Cochrane, John A. (1991). “A Simple Test of Consumption Insurance.” Journal of Political Economy, 99(5): 957-976.

Cox, Donald (1987). "Motives for Private Income Transfers." Journal of Political Economy, 95(3): 508-546.

Cullen, Julie Berry and Jonathan Gruber (2000). "Does Unemployment Insurance Crowd Out Spousal Labor Supply?” Journal of Labor Economics, 18(3):546-472.

Deaton, Angus (1992a). Understanding Consumption. Oxford, Clarendon Press.

Deaton, Angus (1992b). "Household Saving in LDCs: Credit Markets, Insurance, and Welfare." Scandinavian Journal of Economics, 94(2): 253-273.

Dehejia, Rajeev, Thomas DeLeire, and Erzo F.P. Luttmer (2005). "Insuring Consumption and Happiness Through Religious Organizations." National Bureau of Economic Research Working Paper No. 11576.

Diener, Ed and Robert Biswas-Diener (2002). "Will Money Increase Subjective WellBeing?” Social Indicators Research, 57: 119-169.

Diener, Ed, Eunkook M. Suh, Richard E. Lucas, and Heidi L. Smith (1999). "Subjective Well-being: Three Decades of Progress." Psychological Bulletin, 125(2): 276-303.

Di Tella, Rafael, John Haisken-De New, and Robert MacCulloch (2005), "Adaptation to Income and Status in an Individual Panel.” Manuscript, Harvard University.

Ellison, Christopher G. (1991). "Religious Involvement and Subjective Well-Being." Journal of Health and Social Behavior, 32(1): 80-99.

Foster, Andrew and Mark Rosenzweig (2001). "Imperfect Commitment, Altruism, and the Family: Evidence from Transfer Behavior in Low-Income Rural Areas." Review of Economics and Statistics, 83(3): 389-407.

Freeman, Richard B. (1986). "Who Escapes? The Relation of Churchgoing and other Background Factors to the Socioeconomic Performance of Black Male Youths from Inner-city Tracts." In Richard B. Freeman and Harry J. Holzer (eds.), The Black Youth Employment Crisis. Chicago, University of Chicago Press: 353-376.

Frey, Bruno S. and Alois Stutzer (2002). "What Can Economists Learn from Happiness Research?" Journal of Economic Literature, 40(2): 402-35.

Friedman, Milton (1957). A Theory of the Consumption Function. Princeton: Princeton University Press.

Gardner, Jonathan and Andrew J. Oswald (2005). "Money and Mental Health: A Study of Medium-Sized Lottery Wins.” Manuscript, University of Warwick. 
Genicot, Garance, and Debraj Ray (2003). "Group Formation in Risk-Sharing Agreements.” Review of Economic Studies, 70(1): 87-113.

Gertler, Paul and Jonathan Gruber (2002). "Insuring Consumption Against Illness." American Economic Review, 92(1): 51-70.

Guiso, Luigi, Paola Sapienza, and Luigi Zingales (2003). "People’s Opium? Religion and Economic Attitudes.” Journal of Monetary Economics, 50 (2003): 225-282.

Gruber, Jonathan (2004). "Pay or Pray? The Impact of Charitable Subsidies on Religious Attendance." Journal of Public Economics, 88(12): 2635-2655.

Gruber, Jonathan (2005). "Religious Market Structure, Religious Participation, and Outcomes: Is Religion Good for You?" Advances in Economic Analysis and Policy, 5(1), Article 5. Available at http://www.bepress.com/bejeap/advances/vol5/iss1/art5.

Gruber, Jonathan and Daniel M. Hungerman (2005). "Faith-Based Charity and Crowd Out during the Great Depression." National Bureau of Economic Research Working Paper No. 11332.

Gruber, Jonathan and Sendhil Mullainathan (2005). "Do Cigarette Taxes Make Smokers Happier?" Advances in Economic Analysis and Policy, 5(1), Article 4. Available at http://www.bepress.com/bejeap/advances/vol5/iss1/art4

Hungerman, Daniel M. (2005). "Are Church and State Substitutes? Evidence from the 1996 Welfare Reform.” Journal of Public Economics, 89(11-12): 2245-67.

Iannaccone, Laurence R. (1990). "Religious Participation: A Human Capital Approach." Journal for the Scientific Study of Religion, 29(3): 297-314.

Iannaccone, Laurence R. (1992). "Sacrifice and Stigma: Reducing Free-riding in Cults, Communes, and Other Collectives.” Journal of Political Economy, 100(2): 271-291.

Iannaccone, Laurence R. (1998). "Introduction to the Economics of Religion." Journal of Economic Literature, 36(3): 1465-1495.

Leland, Hayne E. (1968). "Saving and Uncertainty." Quarterly Journal of Economics, 82(3):465-473.

MacCulloch, Robert and Silvia Pezzini (2004). "The Role of Freedom, Growth and Religion in the Taste for Revolution." Manuscript, Imperial College London.

Mace, Barbara J. (1991). "Full Insurance in the Presence of Aggregate Uncertainty." Journal of Political Economy, 99(5): 928-56. 
McCullough, Michael E., William T. Hoyt, David B. Larson, Harold G. Koenig, and Carl Thoresen (2000). "Religious Involvement and Mortality: A Meta-Analytic Review." Health Psychology, 19(3): 211-222.

Nelson, Julie A. (1994). “On Testing for Full Insurance using Consumer Expenditure Survey Data." Journal of Political Economy, 102(2): 384-394.

Nelson, Timothy J. (1997). "The Church and the Street: Race and Poverty in an InnerCity Congregation." In Contemporary American Religion: An Ethnographic Reader, edited by Penny Edgell Becker and Nancy Eiesland. Alta Mira Press.

Nelson, Timothy J. (2004). Every Time I Feel the Spirit: Religious Ritual and Experience in an African American Church. New York: New York University Press.

Pargament, Kenneth I. (2002). "The Bitter and the Sweet: An Evaluation of the Costs and Benefits of Religiousness.” Psychological Inquiry, 13(3): 168-181.

Putman, Robert D. (2000). Bowling Alone: The Collapse and Revival of American Community. New York: Simon \& Schuster.

Stasavage, David, and Ken Scheve (2005). "Religion and Preferences for Social Insurance." Manuscript, London School of Economics.

Stasavage, David, and Ken Scheve (2006). "The Political Economy of Religion and Social Insurance in the United States, 1910-1939," Manuscript, London School of Economics.

Strawbridge, William J., Sarah J. Shema, Richard D. Cohen, Robert E. Roberts, and George A. Kaplan (1998). "Religiosity Buffers Effects of Some Stressors on Depression but Exacerbates Others." Journals of Gerontology, 53B(3): 118-126.

Smith, Timothy B., Michael E. McCullough, and Justin Poll (2003). "Religiousness and Depression: Evidence for a Main Effect and the Moderating Influence of Stressful Life Events." Psychological Bulletin, 129(4): 614-636.

Sweet, James A., and Larry L. Bumpass (1996). "The National Survey of Families and Households - Waves 1 and 2: Data Description and Documentation," Center for Demography and Ecology, University of Wisconsin-Madison (http://www.ssc.wisc.edu/nsfh/home.htm).

Sweet, James A., Larry L. Bumpass, and Vaughn Call (1988). "The Design and Content of The National Survey of Families and Households," Center for Demography and Ecology, University of Wisconsin-Madison, NSFH Working Paper No. 1.

Townsend, Robert M. (1994). "Risk and Insurance in Village India." Econometrica, 62(3): 539-591. 
Table 1: Distribution of Religious Attendance

\begin{tabular}{|c|c|c|c|}
\hline & Full Sample & White & Black \\
\hline $\begin{array}{c}\text { in own } \\
\text { distribution }\end{array}$ & $\begin{array}{c}\text { Times / } \\
\text { year }\end{array}$ & $\begin{array}{c}\text { Times / } \\
\text { year }\end{array}$ & $\begin{array}{c}\text { Times / } \\
\text { year }\end{array}$ \\
\hline $1 \%$ & 0 & 0 & 0 \\
\hline $5 \%$ & 0 & 0 & 0 \\
\hline $10 \%$ & 0 & 0 & 1 \\
\hline $25 \%$ & 1 & 1 & 7 \\
\hline $50 \%$ & 13 & 12 & 27 \\
\hline $75 \%$ & 50 & 44 & 52 \\
\hline $90 \%$ & 78 & 76 & 104 \\
\hline $95 \%$ & 104 & 104 & 156 \\
\hline $99 \%$ & 189 & 182 & 234 \\
\hline Mean & 29.3 & 27.1 & 40.7 \\
\hline Std. deviation & 40.4 & 38.0 & 48.3 \\
\hline $\mathrm{N}$ & 5716 & 4697 & 924 \\
\hline
\end{tabular}


Table 2: Religious Organization Membership and Consumption Effects of Income Shocks

\begin{tabular}{|c|c|c|c|c|c|c|}
\hline \multirow[b]{2}{*}{ Variable } & \multicolumn{2}{|c|}{ Full Sample } & \multicolumn{2}{|c|}{ White } & \multicolumn{2}{|c|}{ Black } \\
\hline & Coeff. & (S.E.) & Coeff. & (S.E.) & Coeff. & (S.E.) \\
\hline \multicolumn{7}{|l|}{ a. Baseline specification } \\
\hline Change in ln HH income & $0.115^{* *}$ & $(0.012)$ & $0.113^{* *}$ & $(0.012)$ & $0.108^{* *}$ & $(0.038)$ \\
\hline Member of a religious organization & 0.008 & $(0.012)$ & 0.011 & $(0.013)$ & -0.015 & $(0.026)$ \\
\hline Interaction & $-0.046^{*}$ & $(0.025)$ & $-0.045^{*}$ & $(0.027)$ & -0.068 & $(0.069)$ \\
\hline Implied degree of insurance & $0.397 * *$ & $(0.087)$ & $0.399 * *$ & (0.094) & 0.636 & $(0.419)$ \\
\hline Adjusted $\mathrm{R}^{2}$ & \multicolumn{2}{|c|}{0.0215} & \multicolumn{2}{|c|}{0.0217} & \multicolumn{2}{|c|}{0.0764} \\
\hline
\end{tabular}

b. Horserace between actual and predicted membership

\begin{tabular}{lllllrr} 
Change in ln HH income & $0.124^{* *}$ & $(0.026)$ & $0.127^{* *}$ & $(0.029)$ & 0.070 & $(0.070)$ \\
Member of a religious organization & 0.008 & \multicolumn{7}{c}{$(0.012)$} & 0.011 & $(0.013)$ & -0.013 & $(0.026)$ \\
Predicted membership & \multicolumn{7}{c}{ (absorbed by demographic controls) } \\
Interaction with actual membership & -0.042 & $(0.029)$ & -0.040 & $(0.032)$ & -0.081 & $(0.076)$ \\
Interaction with predicted membership & -0.031 & $(0.083)$ & -0.046 & $(0.094)$ & 0.125 & $(0.207)$ \\
Implied degree of insurance & 0.342 & $(0.243)$ & 0.315 & $(0.267)$ & 1.152 & $(1.773)$ \\
Adjusted R ${ }^{2}$ & \multicolumn{2}{c}{0.0215} & \multicolumn{2}{c}{0.0217} & 0.0776
\end{tabular}

c. Matched sample

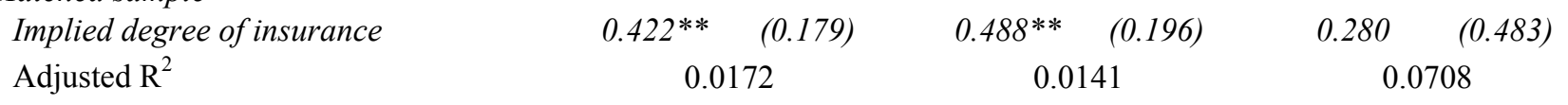

d. Horserace between charitable contributions and church membership

Member of a religious organization

Made charitable contribution

$0.004 \quad(0.010)$

$0.111 * * \quad(0.017) \quad 0.082 * *$

$\begin{array}{lll}0.007 & (0.011) \quad-0.028\end{array}$

$(0.036)$

Interaction with religious membership

$0.010 \quad(0.008)$

0.007

$(0.008) \quad 0.030$

$(0.024)$

Interaction with charitable contribution

$-0.046^{* *} \quad(0.021)$

$-0.055^{* *}$

$(0.024)$

0.021

$(0.035)$

$-0.006 \quad(0.023)$

$-0.001$

$(0.028)$

$-0.042$

$(0.054)$

Implied degree of insurance (religious)

$0.418^{* *} \quad(0.159)$

$0.500 * *$

$(0.137)$

$-0.251$

$(0.084)$

Implied degree of insurance (charity)

$0.055 \quad(0.126)$

0.009

(0.152)

0.505

$(0.521)$

0.0195

0.0197

0.0658

e. Change in log total consumption expenditure used as dependent variable

Implied degree of insurance

Adjusted $\mathrm{R}^{2}$

f. No age restriction on the sample

Implied degree of insurance

Adjusted R ${ }^{2}$
$0.171^{* *} \quad(0.053)$
0.0371
$0.439 * * \quad(0.073)$
0.0195

$0.193 * * \quad(0.060)$

0.0367
$0.503 * * \quad(0.088)$
0.0196

0.217

(0.137) 0.0927

$-0.129 \quad(0.477)$ 0.0654

\footnotetext{
Note: Standard errors are calculated accounting for the complex survey design of the CEX and are reported between parenthesis. Standard errror for the implied degree of insurance is calculated by the delta method. Significance levels: *: 10 percent; ** 5 percent.All regressions also include the controls for log real household income, a dummy for income being zero or missing, average age of head and spouse, age squared/100, household size the change in household size between interviews, the presence of children in the household, the change in the presence of children between interviews, education (dummy variables for high school graduate, some college, college graduate, professional degree), marital status (dummy variables for widowed, divorced, separated, and never married), change in marital status, a dummy for owning a life insurance policy, and year by month dummies. The sample sizes for the total, white, and black samples are 31787, 27,190, and 3,322 respectively.
} 
Table 3: Consumption Effects by Respondent Characteristics

\begin{tabular}{|c|c|c|c|c|c|c|c|c|c|c|c|c|}
\hline \multirow[b]{3}{*}{ Respondent characteristic } & \multicolumn{6}{|c|}{ Whites } & \multicolumn{6}{|c|}{ Blacks } \\
\hline & $\begin{array}{l}\Delta \ln \mathrm{HH} \\
\text { income }\end{array}$ & Membership & Interaction & $\begin{array}{c}\text { Implied } \\
\text { degree of } \\
\text { insurance }\end{array}$ & & & $\begin{array}{l}\Delta \ln \mathrm{HH} \\
\text { income }\end{array}$ & Membership & Interaction & $\begin{array}{c}\text { Implied } \\
\text { degree of } \\
\text { insurance }\end{array}$ & & \\
\hline & $\begin{array}{l}\text { Coeff. } \\
\text { (S.E.) }\end{array}$ & $\begin{array}{l}\text { Coeff. } \\
\text { (S.E.) }\end{array}$ & $\begin{array}{l}\text { Coeff. } \\
\text { (S.E.) }\end{array}$ & $\begin{array}{l}\text { Coeff. } \\
\text { (S.E.) }\end{array}$ & Adj. $R^{2}$ & $\mathrm{~N}$ & $\begin{array}{l}\text { Coeff. } \\
\text { (S.E.) }\end{array}$ & $\begin{array}{l}\text { Coeff. } \\
\text { (S.E.) }\end{array}$ & $\begin{array}{l}\text { Coeff. } \\
\text { (S.E.) }\end{array}$ & $\begin{array}{l}\text { Coeff. } \\
\text { (S.E.) }\end{array}$ & Adj. $\mathrm{R}^{2}$ & $\mathrm{~N}$ \\
\hline \multicolumn{13}{|c|}{ a. By educational attainment } \\
\hline High school or less & $\begin{array}{c}0.123 * * \\
(0.018)\end{array}$ & $\begin{array}{c}0.005 \\
(0.021)\end{array}$ & $\begin{array}{c}-0.065 \\
(0.043)\end{array}$ & $\begin{array}{l}0.524 * * \\
(0.157)\end{array}$ & 0.0330 & 11588 & $\begin{array}{l}0.126^{* *} \\
(0.042)\end{array}$ & $\begin{array}{c}-0.022 \\
(0.044)\end{array}$ & $\begin{array}{c}-0.127 * \\
(0.067)\end{array}$ & $\begin{array}{c}1.007 * \\
(0.528)\end{array}$ & 0.1068 & 1919 \\
\hline Some college or more & $\begin{array}{l}0.095 * * \\
(0.023)\end{array}$ & $\begin{array}{c}0.017 \\
(0.015)\end{array}$ & $\begin{array}{c}-0.027 \\
(0.038)\end{array}$ & $\begin{array}{c}0.283 \\
(0.204)\end{array}$ & 0.0271 & 15602 & $\begin{array}{c}0.049 \\
(0.082)\end{array}$ & $\begin{array}{c}0.003 \\
(0.058)\end{array}$ & $\begin{array}{c}0.037 \\
(0.132)\end{array}$ & $\begin{array}{l}-0.757 \\
(3.271)\end{array}$ & 0.1453 & 1403 \\
\hline \multicolumn{13}{|c|}{ b. By liquid financial assets } \\
\hline$\$ 2000$ or less & $\begin{array}{c}0.114 * * \\
(0.016)\end{array}$ & $\begin{array}{c}0.019 \\
(0.018)\end{array}$ & $\begin{array}{c}-0.047 \\
(0.039)\end{array}$ & $\begin{array}{l}0.412 * * \\
(0.113)\end{array}$ & 0.0347 & 13580 & $\begin{array}{l}0.119 * * \\
(0.033)\end{array}$ & $\begin{array}{c}-0.034 \\
(0.031)\end{array}$ & $\begin{array}{c}-0.103 \\
(0.077)\end{array}$ & $\begin{array}{c}0.869 \\
(0.583)\end{array}$ & 0.0946 & 2612 \\
\hline More than $\$ 2000$ & $\begin{array}{l}0.094 * * \\
(0.028)\end{array}$ & $\begin{array}{l}-0.004 \\
(0.017)\end{array}$ & $\begin{array}{c}-0.032 \\
(0.048)\end{array}$ & $\begin{array}{c}0.335 \\
(0.216)\end{array}$ & 0.0306 & 13610 & $\begin{array}{c}0.020 \\
(0.159)\end{array}$ & $\begin{array}{c}0.056 \\
(0.093)\end{array}$ & $\begin{array}{c}0.058 \\
(0.172)\end{array}$ & $\begin{array}{l}-2.826 \\
(9.290)\end{array}$ & 0.2915 & 710 \\
\hline \multicolumn{13}{|l|}{ c. By per capita income } \\
\hline$\$ 15000$ or less & $\begin{array}{l}0.090 * * \\
(0.017)\end{array}$ & $\begin{array}{c}0.002 \\
(0.019)\end{array}$ & $\begin{array}{c}-0.062 \\
(0.032)\end{array}$ & $\begin{array}{l}0.687 * * \\
(0.190)\end{array}$ & 0.0291 & 13358 & $\begin{array}{l}0.106^{* *} \\
(0.037)\end{array}$ & $\begin{array}{c}-0.011 \\
(0.039)\end{array}$ & $\begin{array}{c}-0.064 \\
(0.086)\end{array}$ & $\begin{array}{c}0.600 \\
(0.527)\end{array}$ & 0.1002 & 2322 \\
\hline More than $\$ 15000$ & $\begin{array}{l}0.147^{* *} \\
(0.023)\end{array}$ & $\begin{array}{c}0.021 \\
(0.015)\end{array}$ & $\begin{array}{c}-0.030 \\
(0.043)\end{array}$ & $\begin{array}{c}0.206^{*} \\
(0.129)\end{array}$ & 0.0319 & 13832 & $\begin{array}{c}0.167 \\
(0.134)\end{array}$ & $\begin{array}{c}-0.069 \\
(0.077)\end{array}$ & $\begin{array}{c}-0.124 \\
(0.173)\end{array}$ & $\begin{array}{c}0.742 \\
(0.630)\end{array}$ & 0.1757 & 1000 \\
\hline
\end{tabular}

Note: Standard errors are calculated accounting for the complex survey design of the CEX and are reported between parenthesis. Significance levels: *: 10 percent; ** 5 percent. All regressions also include the controls from the baseline regression (table 2, panel a). Financial assets and per capita income are measured in 2005 constant dollars. 


\begin{tabular}{lllllll}
\multirow{2}{*}{ Variable } & \multicolumn{2}{c}{ Full Sample } & \multicolumn{2}{c}{ White } & \multicolumn{2}{c}{ Black } \\
\cline { 2 - 7 } & Coeff. & (S.E.) & Coeff. & (S.E.) & Coeff. & (S.E.) \\
\hline
\end{tabular}

a. Baseline Specification

\begin{tabular}{lllllll} 
Change in ln HH income & $0.267^{* *}$ & $(0.102)$ & 0.181 & $(0.110)$ & $0.780^{* *}$ & $(0.323)$ \\
Religious attendance (percentile) & -0.131 & $(0.111)$ & -0.073 & $(0.119)$ & -0.506 & $(0.377)$ \\
Interaction & -0.262 & $(0.183)$ & -0.104 & $(0.202)$ & $-1.164 * *$ & $(0.516)$ \\
Implied degree of insurance & $0.649^{*}$ & $(0.352)$ & 0.335 & $(0.569)$ & $1.189^{* *}$ & $(0.333)$ \\
Adjusted $\mathrm{R}^{2}$ & \multicolumn{2}{c}{0.0290} & \multicolumn{2}{c}{0.0365} & 0.0215
\end{tabular}

b. Horserace between actual and predicted attendance

\begin{tabular}{lcccccc} 
Change in ln HH income & $0.277^{* *}$ & $(0.115)$ & $0.222^{*}$ & $(0.121)$ & $0.717^{*}$ & $(0.401)$ \\
Actual religious attendance & -0.095 & $(0.116)$ & -0.024 & $(0.123)$ & -0.687 & $(0.419)$ \\
Predicted religious attendance & \multicolumn{2}{c}{ (absorbed by demographic controls) } & & \\
Interaction with actual att. & -0.283 & $(0.213)$ & -0.189 & $(0.231)$ & -1.049 & $(0.661)$ \\
Interaction with predicted att. & 0.101 & $(0.454)$ & 0.408 & $(0.510)$ & -0.347 & $(1.306)$ \\
Implied degree of insurance & $0.687^{*}$ & $(0.387)$ & 0.541 & $(0.533)$ & $1.153^{* *}$ & $(0.371)$ \\
Adjusted R $\mathrm{R}^{2}$ & \multicolumn{7}{c}{0.0289} & 0.0365 & 0.0217
\end{tabular}

c. Matched Sample

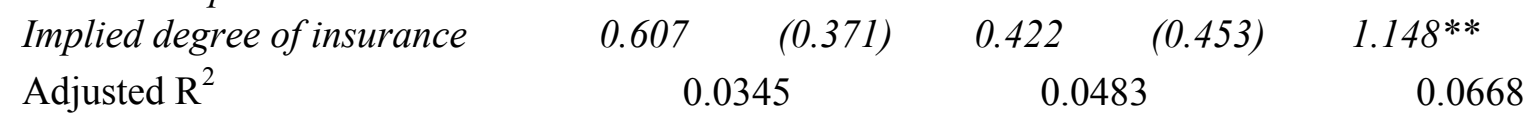

d. Ordered Probit

$\begin{array}{lccccc}\text { Implied degree of insurance } & 0.609^{*} & (0.341) & 0.250 & (0.548) & 1.227^{* *}\end{array}$ (0.341)

e. Attending more than the race-specific median

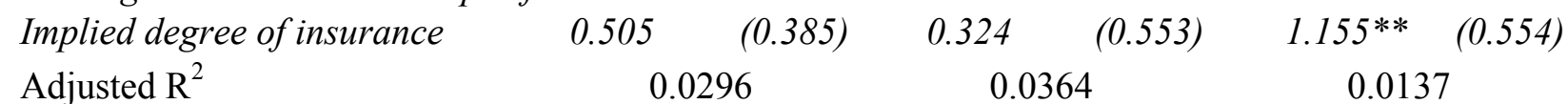

f. No age restriction on the sample

$\begin{array}{lllllll}\text { Implied degree of insurance } & 0.687 * * & (0.307) & 0.541 & (0.459) & 0.999 * * & (0.308)\end{array}$

$\begin{array}{llll}\text { Adjusted } \mathrm{R}^{2} & 0.0293 & 0.0347 & 0.0203\end{array}$

\footnotetext{
Note: Robust standard errors between parenthesis. Significance levels: *: 10 percent; ** 5 percent. All regressions also include controls for log real household income, employment by gender, employment change by gender, age, age squared, gender, household size, the change in household size between interviews, any children under 18 in the household, the change the presence of chidren in the household, education (dummy variables for high school graduate, some college, college graduate, professional degree), marital status (dummy variables for widowed, divorced, separated, and never married), change in marital status, race (black and other race-ethnicity), religious affiliation (12 dummies), private health insurance coverage in wave 2, and year by month dummies. Independent variables with missing values or logs of dollar amounts less than $\$ 100 /$ year are dummied out. The sample sizes for the full, white and black sample are 5716, 4697 and 924 respectively. In the matched sample, the sample sizes are 4123, 3299 and 665 respectively.
} 


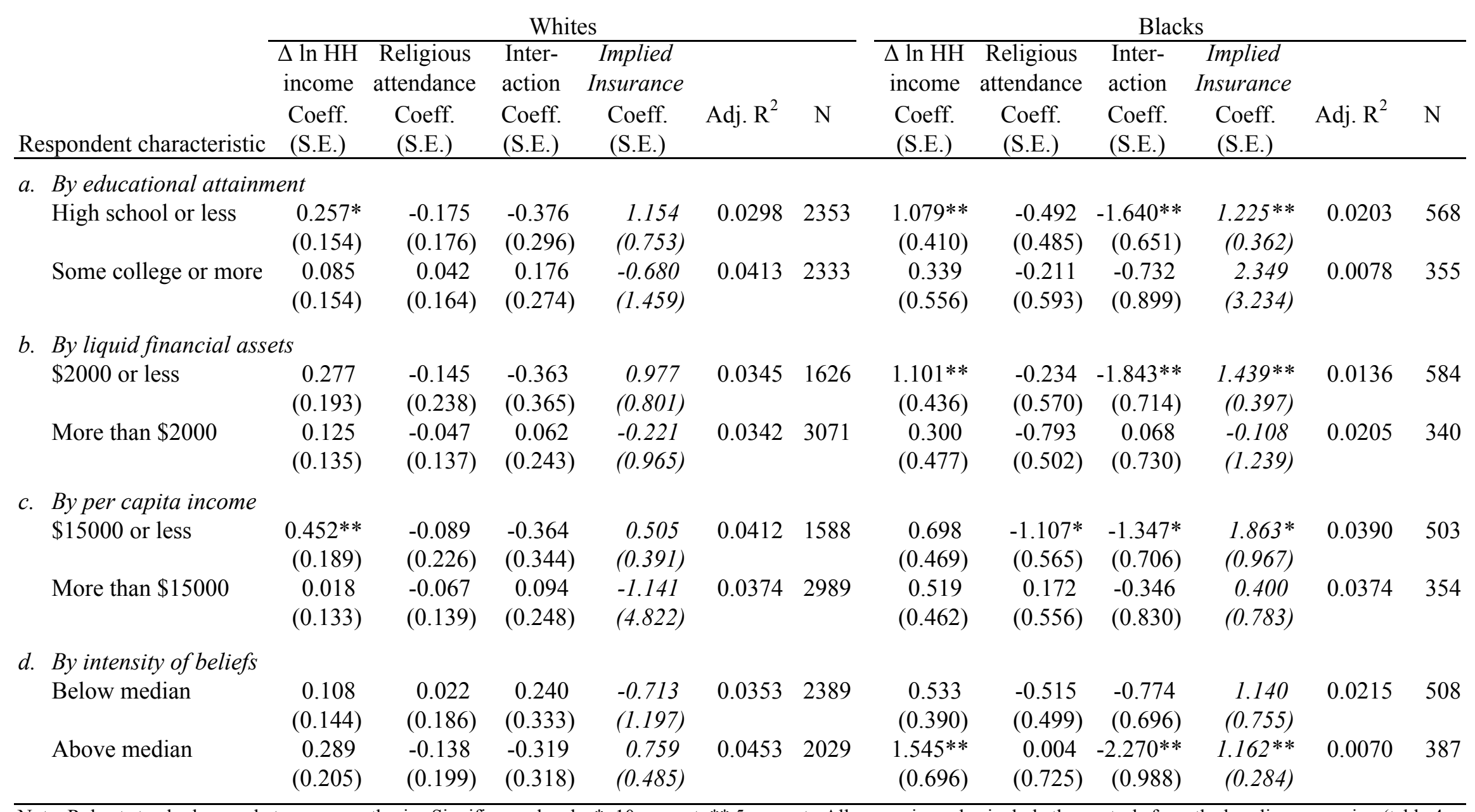

Note: Robust standard errors between parenthesis. Significance levels: *: 10 percent; ** 5 percent. All regressions also include the controls from the baseline regression (table 4 , panel a). Financial assets and per capita income are measured in 2005 constant dollars. The median of belief intensity is determined relative to the own sample. 


\begin{tabular}{|c|c|c|c|c|c|c|c|c|c|c|c|c|}
\hline \multirow[b]{2}{*}{ Mechanism } & \multicolumn{6}{|c|}{ Whites } & \multicolumn{6}{|c|}{ Blacks } \\
\hline & $\begin{array}{r}\Delta \ln \mathrm{HH} \\
\text { income } \\
\text { Coeff. } \\
\text { (S.E.) }\end{array}$ & $\begin{array}{r}\text { Activity } \\
\text { Coeff. } \\
\text { (S.E.) }\end{array}$ & $\begin{array}{c}\text { Inter- } \\
\text { action } \\
\text { Coeff. } \\
\text { (S.E.) }\end{array}$ & $\begin{array}{r}\text { Implied } \\
\text { Insurance } \\
\text { Coeff. } \\
\text { (S.E.) }\end{array}$ & Adj. $\mathrm{R}^{2}$ & $\mathrm{~N}$ & $\begin{array}{r}\Delta \ln H H \\
\text { income } \\
\text { Coeff. } \\
\text { (S.E.) }\end{array}$ & $\begin{array}{r}\text { Activity } \\
\text { Coeff. } \\
\text { (S.E.) }\end{array}$ & $\begin{array}{l}\text { Inter- } \\
\text { action } \\
\text { Coeff. } \\
\text { (S.E.) }\end{array}$ & $\begin{array}{r}\text { Implied } \\
\text { Insurance } \\
\text { Coeff. } \\
\text { (S.E.) }\end{array}$ & Adj. $\mathrm{R}^{2}$ & $\mathrm{~N}$ \\
\hline \multicolumn{13}{|l|}{ a. Social Activities } \\
\hline $\begin{array}{l}\text { Getting together socially with } \\
\text { friends / neighbors / relatives / }\end{array}$ & $\begin{array}{l}0.210 \\
(0.167)\end{array}$ & $\begin{array}{l}-0.014 \\
\quad(0.052)\end{array}$ & $\begin{array}{l}-0.041 \\
(0.090)\end{array}$ & $\begin{array}{c}0.485 \\
(0.885)\end{array}$ & 0.0365 & 4697 & $\begin{array}{l}0.516^{*} \\
(0.289)\end{array}$ & $\begin{array}{r}-0.335 * * \\
(0.109)\end{array}$ & $\begin{array}{r}-0.234 \\
\quad(0.152)\end{array}$ & $\begin{array}{l}1.662^{*} \\
(0.877)\end{array}$ & 0.0257 & 924 \\
\hline Group recreational activity & $\begin{array}{l}0.147 * \\
(0.079)\end{array}$ & $\begin{array}{l}-0.005 \\
\quad(0.027)\end{array}$ & $\begin{array}{l}-0.014 \\
(0.048)\end{array}$ & $\begin{array}{c}0.206 \\
(0.707)\end{array}$ & 0.0356 & 4697 & $\begin{array}{l}0.204 \\
(0.189)\end{array}$ & $\begin{array}{l}-0.032 \\
(0.080)\end{array}$ & $\begin{array}{l}-0.067 \\
(0.117)\end{array}$ & $\begin{array}{l}0.989 \\
(1.805)\end{array}$ & 0.0146 & 924 \\
\hline Going to a bar & $\begin{array}{l}0.089 \\
(0.074)\end{array}$ & $\begin{array}{l}0.038 \\
(0.031)\end{array}$ & $\begin{array}{l}0.045 \\
(0.051)\end{array}$ & $\begin{array}{l}-0.671 \\
(0.797)\end{array}$ & 0.0363 & 4697 & $\begin{array}{l}0.227 \\
(0.175)\end{array}$ & $\begin{array}{l}-0.037 \\
(0.095)\end{array}$ & $\begin{array}{l}-0.124 \\
\quad(0.126)\end{array}$ & $\begin{array}{l}2.423 \\
(3.987)\end{array}$ & 0.0122 & 924 \\
\hline $\begin{array}{l}\text { Going to social event at church / } \\
\text { synagogue / mosque }\end{array}$ & $\begin{array}{r}0.182 * * \\
(0.075)\end{array}$ & $\begin{array}{l}-0.023 \\
(0.039)\end{array}$ & $\begin{array}{l}-0.051 \\
(0.052)\end{array}$ & $\begin{array}{c}0.783 \\
(0.870)\end{array}$ & 0.0366 & 4697 & $\begin{array}{r}0.487 * * \\
(0.238)\end{array}$ & $\begin{array}{l}0.141 \\
(0.101)\end{array}$ & $\begin{array}{r}-0.226^{*} \\
\quad(0.118)\end{array}$ & $\begin{array}{l}1.734^{*} \\
(0.926)\end{array}$ & 0.0191 & 924 \\
\hline $\begin{array}{l}\text { b. Activity in organizations } \\
\text { Service or political organization }\end{array}$ & $\begin{array}{r}0.202 * * \\
(0.065)\end{array}$ & $\begin{array}{l}0.001 \\
(0.073)\end{array}$ & $\begin{array}{r}-0.280 * * \\
(0.138)\end{array}$ & $\begin{array}{r}1.384 * * \\
(0.592)\end{array}$ & 0.0371 & 4697 & $\begin{array}{l}0.137 \\
(0.158)\end{array}$ & $\begin{array}{l}0.162 \\
(0.201)\end{array}$ & $\begin{array}{l}-0.036 \\
\quad(0.331)\end{array}$ & $\begin{array}{l}0.261 \\
(2.249)\end{array}$ & 0.0226 & 924 \\
\hline Work-related organization & $\begin{array}{l}0.120^{*} \\
(0.068)\end{array}$ & $\begin{array}{l}0.026 \\
(0.072)\end{array}$ & $\begin{array}{l}0.044 \\
(0.125)\end{array}$ & $\begin{array}{l}-0.370 \\
(0.592)\end{array}$ & 0.0364 & 4697 & $\begin{array}{l}0.121 \\
(0.168)\end{array}$ & $\begin{array}{r}0.529 * * \\
(0.202)\end{array}$ & $\begin{array}{l}0.032 \\
(0.317)\end{array}$ & $\begin{array}{r}-0.266 \\
(2.882)\end{array}$ & 0.0283 & 924 \\
\hline Leisure groups & $\begin{array}{l}0.148 * \\
(0.085)\end{array}$ & $\begin{array}{r}-0.137 * * \\
(0.069)\end{array}$ & $\begin{array}{l}-0.031 \\
(0.120)\end{array}$ & $\begin{array}{c}0.206 \\
(0.721)\end{array}$ & 0.0368 & 4697 & $\begin{array}{l}0.090 \\
(0.210)\end{array}$ & $\begin{array}{l}0.187 \\
(0.200)\end{array}$ & $\begin{array}{l}0.113 \\
(0.324)\end{array}$ & $\begin{array}{r}-1.263 \\
\quad(6.218)\end{array}$ & 0.0147 & 924 \\
\hline Religious organizations & $\begin{array}{r}0.191 * * \\
(0.074)\end{array}$ & $\begin{array}{l}-0.117 \\
\quad(0.085)\end{array}$ & $\begin{array}{l}-0.150 \\
(0.120)\end{array}$ & $\begin{array}{c}0.785 \\
(0.485)\end{array}$ & 0.0377 & 4697 & $\begin{array}{l}0.330 \\
(0.236)\end{array}$ & $\begin{array}{l}0.198 \\
(0.207)\end{array}$ & $\begin{array}{c}-0.346 \\
(0.301)\end{array}$ & $\begin{array}{r}1.048 * * \\
(0.492)\end{array}$ & 0.0145 & 924 \\
\hline
\end{tabular}

Note: Robust standard errors between parenthesis. Significance levels: *: 10 percent; ** 5 percent. All regressions also include the controls from the baseline regression (table 4 , panel a). All the variables on social activities are measured on a $0-4$ scale with 0 corresponding to "never", 1 to "several times a year", 2 to "about once a month", 3 to "about once a week" and 4 to "several times p week." For these variables, the implied degree of insurance is the reduction in the happiness impact of income shocks associated with attendance going from 1 to 3 . "Getting together socially with friends / neighbors / relatives / colleagues" is measured as the average of four separate questions asked about getting together socially with each of these classes of people. "Activity in organization equals 1 if the respondent reports to attend at least "several times per year" an event of such an organization. Service and policital organizations include service, fraternal, veterans' and political groups. The sample sizes for the white and black sample are 4697 and 924 respectively. 


\begin{tabular}{|c|c|c|c|c|c|c|}
\hline \multirow[b]{3}{*}{ Variable } & \multicolumn{2}{|c|}{ Full Sample } & \multicolumn{2}{|c|}{ White } & \multicolumn{2}{|c|}{ Black } \\
\hline & \multirow{2}{*}{\multicolumn{2}{|c|}{ Standard }} & \multicolumn{2}{|r|}{ Standard } & \multicolumn{2}{|r|}{ Standard } \\
\hline & & Deviation & Mean & Deviation & Mean & Deviation \\
\hline Contributes to a religious organization & 0.38 & 0.49 & 0.38 & 0.49 & 0.37 & 0.48 \\
\hline Ln HH nondurable consumption & 8.02 & 0.72 & 8.07 & 0.70 & 7.68 & 0.74 \\
\hline $\begin{array}{l}\text { Nondurable consumption (quarterly, in } \\
\text { thousands of } \$ 1998 \text { ) }\end{array}$ & 3.98 & 3.48 & 4.13 & 3.55 & 2.88 & 2.62 \\
\hline$\Delta$ Ln nondurable consumption & -0.015 & 0.717 & -0.012 & 0.722 & -0.035 & 0.679 \\
\hline Ln HH income & 10.42 & 0.79 & 10.48 & 0.77 & 9.98 & 0.84 \\
\hline Missing $\ln$ income & 0.0004 & 0.021 & 0.0005 & 0.022 & 0 & 0 \\
\hline HH income (in thousands of \$1998) & 43.41 & 30.84 & 45.16 & 31.17 & 29.39 & 23.17 \\
\hline$\Delta \mathrm{Ln} \mathrm{HH}$ income & 0.038 & 0.602 & 0.037 & 0.589 & 0.032 & 0.683 \\
\hline$\Delta \mathrm{Ln} \mathrm{HH}$ income (bottom/top coded) & 0.043 & 0.416 & 0.042 & 0.409 & 0.039 & 0.456 \\
\hline Missing $\Delta$ Ln HH income & 0.007 & 0.085 & 0.008 & 0.089 & 0.002 & 0.049 \\
\hline Separated & 0.04 & 0.19 & 0.03 & 0.16 & 0.12 & 0.32 \\
\hline Divorced & 0.14 & 0.35 & 0.14 & 0.34 & 0.17 & 0.38 \\
\hline Widowed & 0.03 & 0.17 & 0.03 & 0.16 & 0.06 & 0.23 \\
\hline Never Married & 0.17 & 0.37 & 0.15 & 0.36 & 0.29 & 0.45 \\
\hline$\Delta$ Separated & -0.0004 & 0.078 & -0.0004 & 0.077 & -0.0013 & 0.089 \\
\hline$\Delta$ Divorced & -0.0006 & 0.094 & -0.0005 & 0.096 & -0.0011 & 0.073 \\
\hline$\Delta$ Widowed & -0.0002 & 0.046 & -0.0003 & 0.044 & 0.0002 & 0.059 \\
\hline$\Delta$ Never Married & -0.0038 & 0.086 & -0.0038 & 0.085 & -0.0042 & 0.094 \\
\hline Kids under 18 present in $\mathrm{HH}$ & 0.45 & 0.49 & 0.44 & 0.49 & 0.55 & 0.49 \\
\hline$\Delta$ Kids under 18 present in $\mathrm{HH}$ & -0.004 & 0.203 & -0.003 & 0.200 & -0.007 & 0.219 \\
\hline Household size & 2.93 & 1.52 & 2.90 & 1.48 & 3.06 & 1.70 \\
\hline$\Delta$ Household size & 0.026 & 0.568 & 0.026 & 0.551 & 0.029 & 0.669 \\
\hline Age & 40.16 & 10.26 & 40.23 & 10.27 & 39.78 & 10.20 \\
\hline $\mathrm{Age}^{2} / 100$ & 17.18 & 8.43 & 17.24 & 8.45 & 16.86 & 8.33 \\
\hline High school & 0.25 & 0.33 & 0.25 & 0.34 & 0.23 & 0.30 \\
\hline Some college & 0.20 & 0.30 & 0.21 & 0.30 & 0.17 & 0.28 \\
\hline College degree & 0.12 & 0.25 & 0.13 & 0.25 & 0.07 & 0.19 \\
\hline Post college degree & 0.09 & 0.22 & 0.09 & 0.23 & 0.04 & 0.15 \\
\hline White & 0.86 & 0.35 & 1 & 0 & 0 & 0 \\
\hline Black & 0.11 & 0.31 & 0 & 0 & 1 & 0 \\
\hline Other race & 0.03 & 0.18 & 0 & 0 & 0 & 0 \\
\hline Ln wealth & 6.19 & 3.98 & 6.52 & 3.88 & 3.60 & 3.79 \\
\hline Wealth zero or missing & 0.23 & 0.42 & 0.20 & 0.40 & 0.47 & 0.50 \\
\hline$\Delta$ Ln wealth & 0.001 & 0.96 & 0.009 & 0.96 & -0.058 & 0.96 \\
\hline Owns home & 0.68 & 0.47 & 0.71 & 0.45 & 0.43 & 0.50 \\
\hline Owns life insurance policy & 0.53 & 0.50 & 0.53 & 0.50 & 0.53 & 0.50 \\
\hline $\mathrm{N}$ & & & & & & \\
\hline
\end{tabular}




\begin{tabular}{|c|c|c|c|c|c|c|}
\hline \multirow[b]{3}{*}{ Variable } & \multicolumn{2}{|c|}{ Full Sample } & \multicolumn{2}{|c|}{ White } & \multicolumn{2}{|c|}{ Black } \\
\hline & & Standard & & Standard & & Standard \\
\hline & Mean & Deviation & Mean & Deviation & Mean & Deviation \\
\hline Self-reported happiness & 5.31 & 1.05 & 5.33 & 1.03 & 5.22 & 1.03 \\
\hline$\Delta$ Self-reported happiness & -0.05 & 1.62 & -0.05 & 1.61 & -0.01 & 1.61 \\
\hline Percentile in religious attendance & 0.48 & 0.25 & 0.46 & 0.26 & 0.57 & 0.23 \\
\hline Ln HH income & 10.08 & 0.86 & 10.16 & 0.81 & 9.61 & 0.81 \\
\hline Missing ln income & 0.04 & 0.20 & 0.03 & 0.18 & 0.08 & 0.18 \\
\hline HH income (in thousands of $\$ 1998$ ) & 55.21 & 52.69 & 58.68 & 55.27 & 36.59 & 31.97 \\
\hline$\Delta \mathrm{Ln} \mathrm{HH}$ income & 0.18 & 0.87 & 0.18 & 0.86 & 0.14 & 0.86 \\
\hline$\Delta \mathrm{Ln} \mathrm{HH}$ income (bottom/top coded) & 0.18 & 0.57 & 0.18 & 0.56 & 0.16 & 0.56 \\
\hline Missing $\Delta \ln$ income & 0.25 & 0.43 & 0.23 & 0.42 & 0.35 & 0.42 \\
\hline Separated & 0.05 & 0.16 & 0.03 & 0.14 & 0.10 & 0.14 \\
\hline Divorced & 0.14 & 0.30 & 0.13 & 0.29 & 0.16 & 0.29 \\
\hline Widowed & 0.02 & 0.14 & 0.02 & 0.12 & 0.05 & 0.12 \\
\hline Never Married & 0.15 & 0.32 & 0.12 & 0.29 & 0.28 & 0.29 \\
\hline$\Delta$ Separated & -0.01 & 0.26 & -0.01 & 0.24 & -0.02 & 0.24 \\
\hline$\Delta$ Divorced & 0.01 & 0.33 & 0.01 & 0.34 & 0.03 & 0.34 \\
\hline$\Delta$ Widowed & 0.01 & 0.13 & 0.01 & 0.12 & 0.02 & 0.12 \\
\hline$\Delta$ Never Married & -0.07 & 0.29 & -0.07 & 0.28 & -0.07 & 0.28 \\
\hline Kids under 18 present in $\mathrm{HH}$ & 0.57 & 0.43 & 0.57 & 0.43 & 0.58 & 0.43 \\
\hline$\Delta$ Kids under 18 present in $\mathrm{HH}$ & -0.03 & 0.49 & -0.02 & 0.49 & -0.07 & 0.49 \\
\hline Household size & 3.23 & 1.36 & 3.19 & 1.31 & 3.39 & 1.31 \\
\hline$\Delta$ Household size & 0.08 & 1.52 & 0.06 & 1.47 & 0.12 & 1.47 \\
\hline Age & 37.03 & 9.09 & 36.91 & 9.02 & 37.74 & 9.02 \\
\hline $\mathrm{Age}^{2} / 100$ & 14.53 & 7.07 & 14.44 & 7.01 & 15.13 & 7.01 \\
\hline High school & 0.38 & 0.48 & 0.38 & 0.48 & 0.38 & 0.48 \\
\hline Some college & 0.26 & 0.44 & 0.26 & 0.44 & 0.27 & 0.44 \\
\hline College degree & 0.11 & 0.31 & 0.12 & 0.32 & 0.07 & 0.32 \\
\hline Post college degree & 0.11 & 0.31 & 0.12 & 0.33 & 0.04 & 0.33 \\
\hline White & 0.82 & 0.38 & 1 & 0 & 0 & 0 \\
\hline Black & 0.16 & 0.37 & 0 & 0 & 1 & 0 \\
\hline Other race & 0.02 & 0.13 & 0 & 0 & 0 & 0 \\
\hline Female & 0.60 & 0.49 & 0.59 & 0.49 & 0.65 & 0.49 \\
\hline Ln wealth & 6.94 & 3.60 & 7.32 & 3.40 & 4.92 & 3.94 \\
\hline Wealth zero or missing & 0.18 & 0.39 & 0.15 & 0.35 & 0.37 & 0.48 \\
\hline$\Delta$ Ln wealth & 0.24 & 1.17 & 0.27 & 1.21 & 0.08 & 0.94 \\
\hline Owns home & 0.57 & 0.43 & 0.61 & 0.42 & 0.40 & 0.44 \\
\hline Covered by private health insurance & 0.78 & 0.40 & 0.79 & 0.39 & 0.68 & 0.45 \\
\hline No religion & 0.06 & 0.23 & 0.06 & 0.24 & 0.03 & 0.24 \\
\hline Jewish & 0.02 & 0.13 & 0.02 & 0.14 & 0.00 & 0.14 \\
\hline Baptist & 0.19 & 0.39 & 0.12 & 0.33 & 0.53 & 0.33 \\
\hline Episcopalian & 0.01 & 0.12 & 0.02 & 0.13 & 0.00 & 0.13 \\
\hline Lutheran & 0.04 & 0.20 & 0.05 & 0.22 & 0.00 & 0.22 \\
\hline
\end{tabular}




\begin{tabular}{lcccccr} 
Methodist & 0.07 & 0.25 & 0.07 & 0.25 & 0.06 & 0.25 \\
Mormon & 0.02 & 0.14 & 0.02 & 0.15 & 0.00 & 0.15 \\
Presbyterian & 0.02 & 0.15 & 0.03 & 0.17 & 0.00 & 0.17 \\
Congregational & 0.01 & 0.08 & 0.01 & 0.08 & 0.00 & 0.08 \\
Protestant, no denomination & 0.01 & 0.09 & 0.01 & 0.10 & 0.00 & 0.10 \\
Other Christian & 0.07 & 0.25 & 0.07 & 0.25 & 0.08 & 0.25 \\
Other religions / missing & 0.01 & 0.08 & 0.00 & 0.06 & 0.01 & 0.06 \\
& & & & & & \\
Frequency of (0-4 scale): & & & & & & \\
$\quad$ Getting together socially with friends / & & & & & & \\
$\quad$ neighbors / relatives / colleagues & 1.27 & 0.66 & 1.27 & 0.64 & 1.25 & 0.64 \\
$\quad$ Group recreational activity & 0.89 & 1.00 & 0.81 & 0.96 & 1.33 & 0.96 \\
$\quad$ Going to a bar & 0.77 & 0.94 & 0.80 & 0.95 & 0.62 & 0.95 \\
$\quad$ Going to social event at church & 0.97 & 1.03 & 1.00 & 1.05 & 0.80 & 1.05 \\
Participation in the following types of organizations: & & & & & \\
$\quad$ Service or policital organization & 0.14 & 0.35 & 0.14 & 0.35 & 0.13 & 0.35 \\
$\quad$ Work-related organization & 0.19 & 0.40 & 0.20 & 0.40 & 0.17 & 0.40 \\
$\quad$ Leisure groups & 0.38 & 0.48 & 0.39 & 0.49 & 0.32 & 0.49 \\
$\quad$ Religious organizations & 0.30 & 0.46 & 0.28 & 0.45 & 0.40 & 0.45 \\
$\quad$ N & 5716 & & & 4697 & & 924 \\
\hline
\end{tabular}

